\title{
A revision of the 1783-1784 Calabrian (southern Italy) tsunamis
}

\author{
L. Graziani ${ }^{1}$, A. Maramai ${ }^{1}$, and S. Tinti ${ }^{2}$ \\ ${ }^{1}$ Istituto Nazionale di Geofisica e Vulcanologia, Sezione Roma 2, Rome, Italy \\ ${ }^{2}$ University of Bologna, Dipartimento di Fisica, Settore Geofisica, Bologna, Italy
}

Received: 28 September 2006 - Revised: 23 November 2006 - Accepted: 23 November 2006 - Published: 13 December 2006

\begin{abstract}
Southern Italy is one of the most tsunamigenic areas in the Mediterranean basin, having experienced during centuries a large number of tsunamis, some of which very destructive. In particular, the most exposed zone here is the Messina Straits separating the coasts of Calabria and Sicily that was the theatre of the strongest Italian events. In 17831785 Calabria was shaken by the most violent and persistent seismic crisis occurred in the last 2000 years. Five very strong earthquakes, followed by tsunamis, occurred in a short interval of time (February-March 1783), causing destruction and a lot of victims in a vast region embracing the whole southern Calabria and the Messina area, Sicily. In this study we re-examined these events by taking into account all available historical sources. In particular, we focussed on the 5 and 6 February 1783 tsunamis, that were the most destructive. As regards the 5 February event, we found that it was underestimated and erroneously considered a minor event. On the contrary, the analysis of the sources revealed that in some localities the tsunami effects were quite strong. The 6 February tsunami, the strongest one of the sequence, was due to a huge earthquake-induced rockfall and killed more than 1500 people in the Calabrian village of Scilla. For this event the inundated area and the runup values distribution were estimated.

Further, the analysis of the historical sources allowed us to find three new tsunamis that passed previously unnoticed and that occurred during this seismic period. The first one occurred a few hours before the large earthquake of 5 February 1783 . The second was generated by a rockfall on 24 March 1783. Finally, the third occurred on 9 January 1784, probably due to a submarine earthquake.
\end{abstract}

\footnotetext{
Correspondence to: A. Maramai

(maramai@ingv.it)
}

\section{Introduction}

In the Mediterranean basin, Italy is one of the countries most affected by tsunamis. During centuries it has experienced a large number of events, some of which caused catastrophic effects, severe damage and thousands of victims. The analysis of the Italian Tsunami Catalogue (ITC, Tinti et al., 2004) shows that southern Calabria, Messina Straits and eastern Sicily are certainly the most active tsunamigenic regions in Italy. As a matter of fact, the majority of the Italian tsunamis, including the strongest ones, occurred here: most were the results of coastal and submarine earthquakes, but some were also due to volcanic activity and submarine slides.

The geological setting of the area is quite complex and some aspects are still poorly understood. Structural analysis and seismological and deformation (VLBI and GPS) data show a regional extensional ESE-WNW trend which is coupled with a strong $1.5-2 \mathrm{~mm} / \mathrm{yr}$ uplift of the whole Calabrian arc region (Monaco et al., 1996; Tortorici et al., 2003; D'Agostino and Selvaggi, 2004; Jenny et al., 2006). One of the main tectonic features is the belt of normal faults running for more than $350 \mathrm{~km}$ along the Apennines chain and extending from Calabria to Sicily, which is formed by distinct fault segments with maximum length of about $40-50 \mathrm{~km}$ that are responsible for the major earthquakes. Some of the faults are found close to the coast or are completely placed offshore with great potential for tsunami generation. The most energetic historical shocks reached the maximum magnitude of M 7 (Boschi et al., 2000) and almost all were accompanied by sizable tsunamis.

Before focusing on the $1783-1785$ seismic period, it is worth mentioning the two largest tsunamigenic earthquakes that occurred in Calabria and Sicily, namely the 1693 eastern Sicily and the December 1908 Messina Straits events (Fig. 1).

At the beginning of 1693 a tremendous seismic crisis hit eastern Sicily, culminating in the main shock of 11 January

Published by Copernicus GmbH on behalf of the European Geosciences Union. 


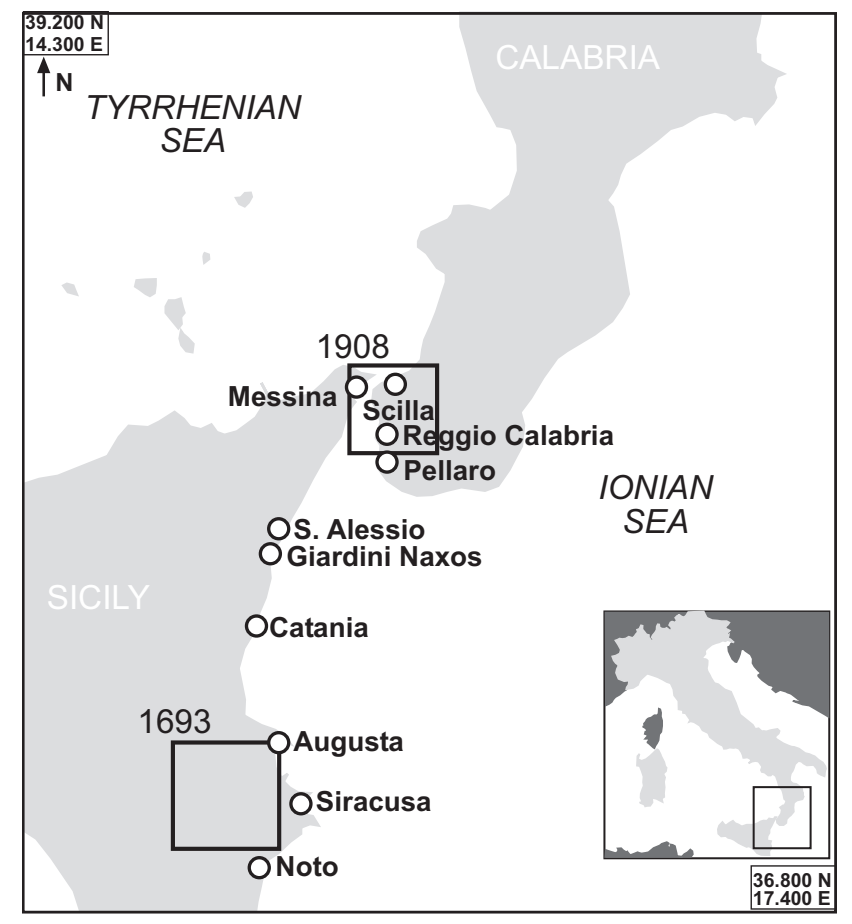

Fig. 1. Epicentres of the earthquakes generating the most destructive tsunamis in southern Calabria and eastern Sicily. Localities most affected by waves are reported.

with estimated magnitude $\mathrm{M}=7.4$ (CPTI2, 2004). It produced almost complete destruction within an area of about $14000 \mathrm{~km}^{2}$ extending from Catania to Noto and Siracusa, causing more than 54000 casualties (Boschi et al., 2000). A tsunami was observed along the whole eastern Sicily coast with major effects at Augusta and Catania. First the sea withdrew from the shoreline and the following inundation was very damaging and lethal for many people. At Augusta, the water waves were likely as high as $15 \mathrm{~m}$ (Tinti et al., 2004).

The 28 December 1908 Messina earthquake is one of the strongest earthquakes that ever occurred in Italy. The towns of Messina and Reggio Calabria together with many other villages were completely destroyed. Partial destruction involved most of Calabria and Sicily over an area about $6000 \mathrm{~km}^{2}$ wide. More than 60000 people died. A violent tsunami followed the shock, causing severe damage and hundreds of victims in the Messina Straits zone. In most places the sea first receded for a few minutes from the usual level and then flooded the coast with at least three big waves. The sea level oscillations lasted for many hours. The tsunami reached its maximum intensity in the Calabrian coast near Pellaro, where run-up heights as large as $13 \mathrm{~m}$ were observed, and in Sicily at Giardini Naxos and at Sant'Alessio, where the measured run up was $11.7 \mathrm{~m}$ (Tinti et al., 2004).

The main purpose of this paper is to provide a picture of the tsunamis that occurred during the seismic crisis that devastated the Calabria region in 1783-1785. Since this seismic sequence was exceptionally long and destructive, the associated tsunamis were almost disregarded as secondary minor events, except for the 6 February Scilla tsunami that caused much more casualties than the parent earthquake itself. This unusual and long seismic period stirred up great interest in many Italian and foreign scientists and scholars, that went on the field to make direct observations and to document the effects. As a result, a vast amount of reports, chronicles, works and maps representing the devastation was produced and this constitutes today a precious source of information for studying the earthquake effects and consequences, including tsunamis. By carrying out a deep analysis of the available sources it was possible to count as many as ten distinct tsunami events, most of low intensity, three of which were never mentioned before in the modern scientific literature. For the largest tsunamis, the available data allowed us to draw a rather reliable picture of the effects and, in particular, for the 6 February Scilla event it was possible to perform the reconstruction of the inundated area and to determine the distribution of the run-up values.

This work contributes to the updating of the ITC (Tinti et al., 2004) and, for this purpose, the events studied here were classified according to the evaluation standards adopted for the catalogue compilation.

\section{The 1783-1785 Calabrian seismic sequence}

In 1783-1785 the southern part of Calabria was struck by one of the most impressive and persistent seismic crisis that occurred in the last 2000 years. A lot of sources are available in the literature: many famous coeval writers and a lot of current historiographer studied and documented this seismic period. During our study we examined more than 100 bibliographical sources, the most reliable ones, and we also performed extensive research in many public and private archives, libraries, etc., in order to collect new data. The crisis lasted more than three years, starting at the beginning of February 1783 and, during a period of about two months five large earthquakes (with epicentral intensity MCS $\geq$ IX) occurred along a zone about $100 \mathrm{~km}$ long, devastating southern Calabria between Reggio Calabria and Catanzaro. The first destructive earthquake of the sequence ocurred on 5 February 1783 , and was followed by the other main shocks respectively on 6 and 7 February, and on 1 and 28 March in the same year. All these earthquakes resulted to be tsunamigenic, though the size of the generated tsunamis differed very much from case to case. The epicentres of the five main shocks migrated northward from the Aspromonte area to the Sant'Eufemia and the Squillace gulfs (Fig. 2). In addition to these main earthquakes, hundreds of smaller aftershocks hit southern Calabria. The seismic sequence was one of most catastrophic in western Europe. The cumulative effects of all these earthquakes was devastating and great changes were produced even in the environment morphology: diffuse 


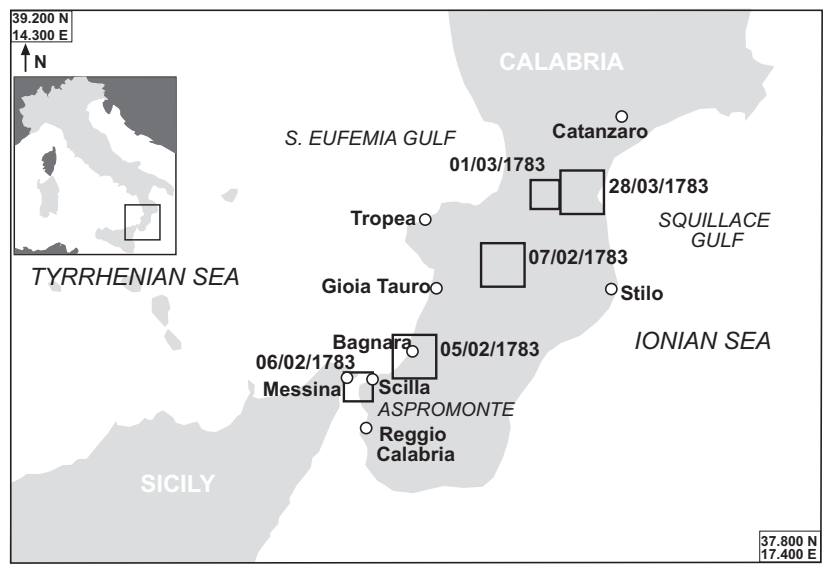

Fig. 2. Epicentres of the five main shocks of the 1783 Calabrian seismic crisis. Square size increases with magnitude.

landsliding led to heavy changes to the hydrogeological system (more than 200 lakes formed as a consequence of stream damming caused by slides). The most extraordinary effects were chiefly due to the 5 February earthquake (Vivenzio, 1788; Hamilton, 1783; Dolomieu, 1784; Baratta, 1901; Jacques et al., 2001).

On the 5 February, at about 12:00, a catastrophic tsunamigenic earthquake abruptly opened the seismic period. The shock (Mw=6.9, I=XI MCS; CPTI2, 2004) was felt in a very wide area, including the whole Sicily and a big portion of the southern Italian peninsula. More than 380 villages were damaged, 180 were almost totally ruined and the count of fatalities exceeded 25000 . Major effects were observed close to the Gioia Tauro plain (on the Tyrrhenian side), at the western foot of the northern Aspromonte, where some towns were completely destroyed and many other suffered severe damage. The Ionian side was less affected. Reports tell that at the time of the shock people in the fields were thrown down and trees were uprooted. Though this event has been widely studied, the identification of the generating fault is still debated. Tsunami information can be used to better define the possible source (Tinti and Piatanesi, 1996a), as was also shown for other cases, where comparison between the available tsunami data and tsunami simulations was used to constrain the focal mechanism as well as to exclude some of the fault locations proposed in literature (see e.g. Piatanesi et al., 1996; Tinti and Piatanesi, 1996b).

The shock of 6 February occurred during the night (00:20), was less strong than the previous day earthquake (equivalent magnitude from macroseismic data $\mathrm{Me}=6.3$, I=VIII-IX; CPTI2, 2004) and was located slightly to south-west, in the Messina Straits. It caused severe damage at Messina and at Scilla. The earthquake was responsible for a huge rockfall that occurred along the western cliff of the Mount Campallà at Scilla, that fell into the sea generating a disastrous tsunami.
Table 1. Reliability scale of the Italian Tsunami Catalogue (Tinti et al., 2004).

\begin{tabular}{l} 
Reliability scale of the Italian Tsunami Catalogue \\
\hline 0: Very Improbable Tsunami \\
1: Improbable Tsunami \\
2: Questionable Tsunami \\
3: Probable Tsunami \\
4: Definite Tsunami \\
\hline
\end{tabular}

On 7 February another big shock, with epicentre located about $40 \mathrm{~km}$ north-east to the 5 February event, hit southern Calabria. The shock $\left(\mathrm{M}_{w}=6.6, \mathrm{I}=\mathrm{X}-\mathrm{XI}\right.$ MCS; CPTI2, 2004) occurred at 13:10 and caused new heavy destruction.

On 1 March at 01:40 the fourth big shock occurred. The estimated magnitude was $\mathrm{M}_{w}=5.9$ (CPTI2, 2004) with $\mathrm{I}=\mathrm{IX}$ MCS and the epicentral area was located about $20 \mathrm{~km}$ north of the 7 February earthquake, along the Apennines chain.

The last big earthquake of the sequence occurred on 28 March at 18:55. The epicentre was slightly west to the fourth, and the estimated magnitude was $\mathrm{M}_{w}=6.9$ with $\mathrm{I}=\mathrm{X}$ MCS (CPTI2, 2004).

\section{The 1783-1784 tsunami events}

In order to perform the reconstruction of the tsunami events that occurred during the 1783-1785 seismic crisis, we gathered the historical material from contemporary chronicles and reports available in national and local libraries, private and ecclesiastic archives, etc. The analysis led us to an improved knowledge of the main events already present in the ITC and to discover three new tsunami events. The tsunamis were examined following the ITC guideline: in particular each event is characterised by a tsunami intensity value, a reliability score and, when known, by the generating mechanism. As far as the intensity is concerned, the 6-degree intensity scale proposed by Sieberg and Ambraseys (Ambraseys, 1962) is used to quantify the effects of a tsunami on structures and environment. An intensity 1 tsunami is "very light" and only visible on tide gauge records, while at the top of the scale an intensity 6 tsunami is capable of causing large disasters with total destruction of man-made structures, extensive flooding, many casualties, etc. Notice that we also attributed the tsunami intensity on the basis of the 12-degree scale that was proposed by Papadopoulos and Imamura in the course of the 2001 International Tsunami Conference, but that was not adopted in the ITC first version (Tinti and Maramai, 1996) nor in its recent update (Tinti et al., 2004).

The tsunami reliability is graded according to the 5-degree modified Iida scale and ranges from degree 0 , equivalent to a "very improbable tsunami", to degree 4 corresponding to a "definite tsunami" (see Table 1). The reliability is a very 


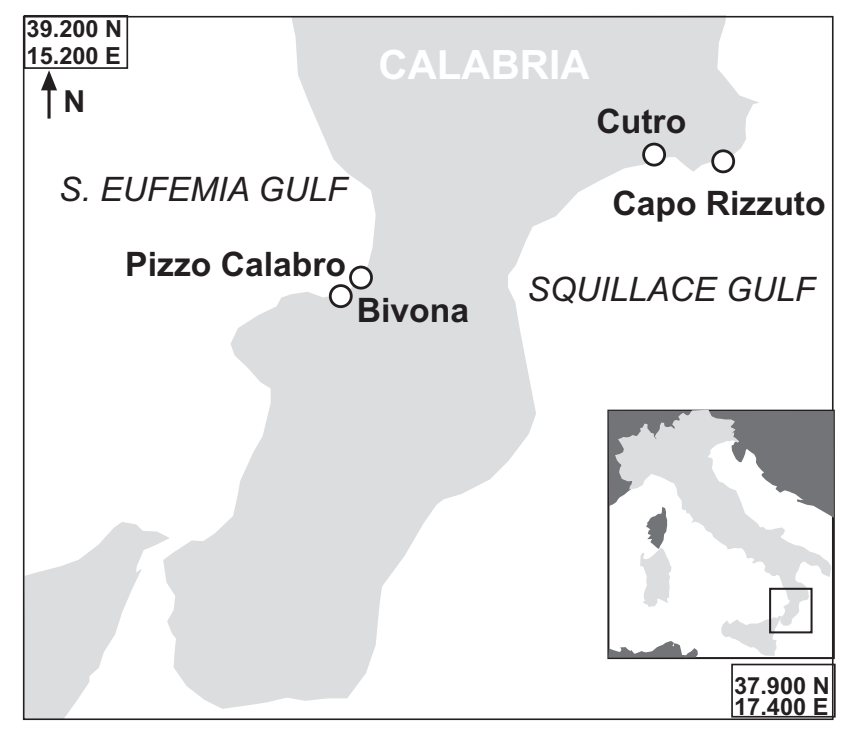

Fig. 3. Localities involved by the tsunami occurred in the morning of 5 February 1783, at 08:00.

important parameter which helps to judge the quality of the data. The approach for determining reliability value consists of taking into account and rating separately different elements or categories of data, namely: 1) what is known about the tsunami cause, 2) what is known about the tsunami itself, and 3) what is known about the documentary sources. Each category is rated on three levels, and then the final reliability is obtained by combining these partial scores (see Tinti et al., 2004, for details on assigning the ITC parameters).

In this research, the result of the scrutiny of new bibliographical sources led us to re-appraise the parameters of some tsunamis that were already included in the ITC. As an example, the 5 February event, that in the catalogue was classified with Ambraseys intensity 3, has been re-evaluated and now classified with intensity 4 .

During the 1783-1785 seismic crisis a total of ten tsunamis occurred all within a time span of about one year from February 1783 to January 1784: seven were small events, two were strong, and one was disastrous, causing more than 1500 victims in the small Calabrian village of Scilla. In the following, a description of each event is provided, with the specification of the tsunami intensity, reliability and cause.

\subsection{February 1783 - time 08:00}

This is one of the three new tsunamis discovered during this study. According to some sources, at about 08:00 in the morning (four hours before the first main shock) a weak earthquake was felt in Calabria (Fig. 3). On the Ionian side of Calabria, at Capo Rizzuto a sudden sea inundation was observed (De Lorenzo, 1877), while at Cutro, some hours before the big earthquake, the sea withdrew and then came back

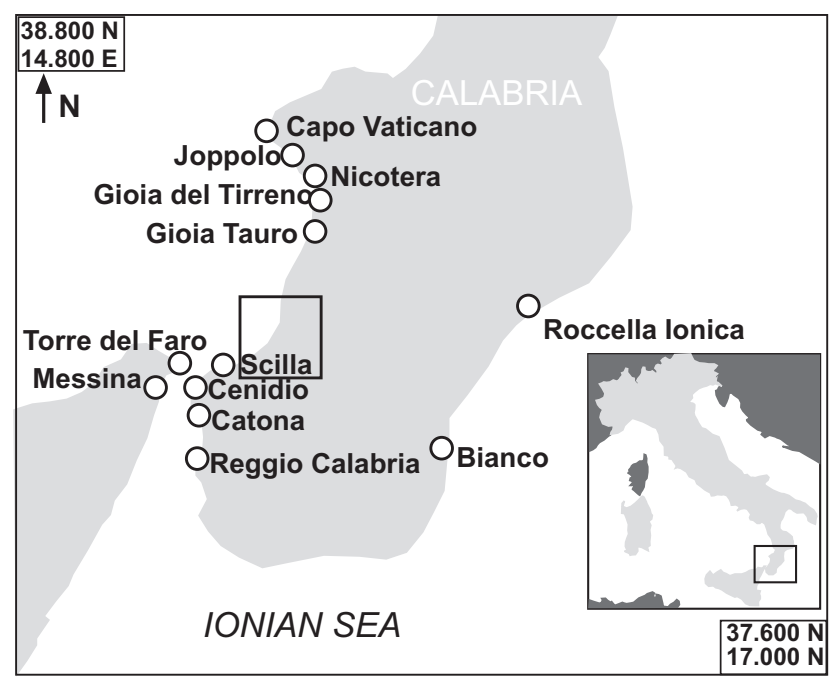

Fig. 4. Epicentre of the 5 February 1783 main shock. Localities hit by the generated tsunami are reported.

to its usual limit (Vivenzio, 1788). On the other hand, De Lorenzo (1877) reports that at Bivona and at Pizzo Calabro, in the Tyrrhenian Calabria, some fishermen on the boat noted that in the morning the sea became suddenly agitated. The only seismic catalogue reporting an earthquake in the morning is the Istituto Nazionale di Geofisica catalogue (ING, 1991), in which a weak shock.(I=III MCS scale) with epicenter located at capo Rizzuto on the Ionian coast is mentioned as occurred at 08:00 in the morning. The intensity attributed to this tsunami is 3 (Sieberg-Ambraseys scale) and the reliability is 2. The estimated Papadopoulos-Imamura scale intensity, hereafter denoted by P-I intensity, is III.

\subsection{February 1783 - time 12:00}

The 5 February tsunami event was at first underestimated and considered only a minor event, causing no serious damage. On the contrary, the analysis of the sources revealed that in some localities the tsunami effects were quite strong. The Sicily coast from Messina to Torre del Faro (about 11 miles) and in Calabria from Cenidio to Scilla (about 7 miles) was heavily affected by the tsunami (Fig. 4). Historical sources refer that generally the sea first receded and then inundated the shore. Withdrawals and inundations repeated at least three times at intervals of about $10-15 \mathrm{~min}$.

At Joppolo a considerable sea withdrawal was observed, that left the sea bottom dry (Sarconi, 1784), and about $8 \mathrm{~min}$ after the shock in the sea between Nicotera and Gioia Tauro two fishermen observed two waves, one travelling toward Capo Vaticano and the other toward Gioia del Tirreno (Galimi, 1783; De Lorenzo, 1877). This latter was as high as a big vessel, but caused no damage (Minasi, 1785).

At Nicotera the sea withdrew boiling and then turned the fishing boats upside-down (Vivenzio, 1788). At Gioia del 


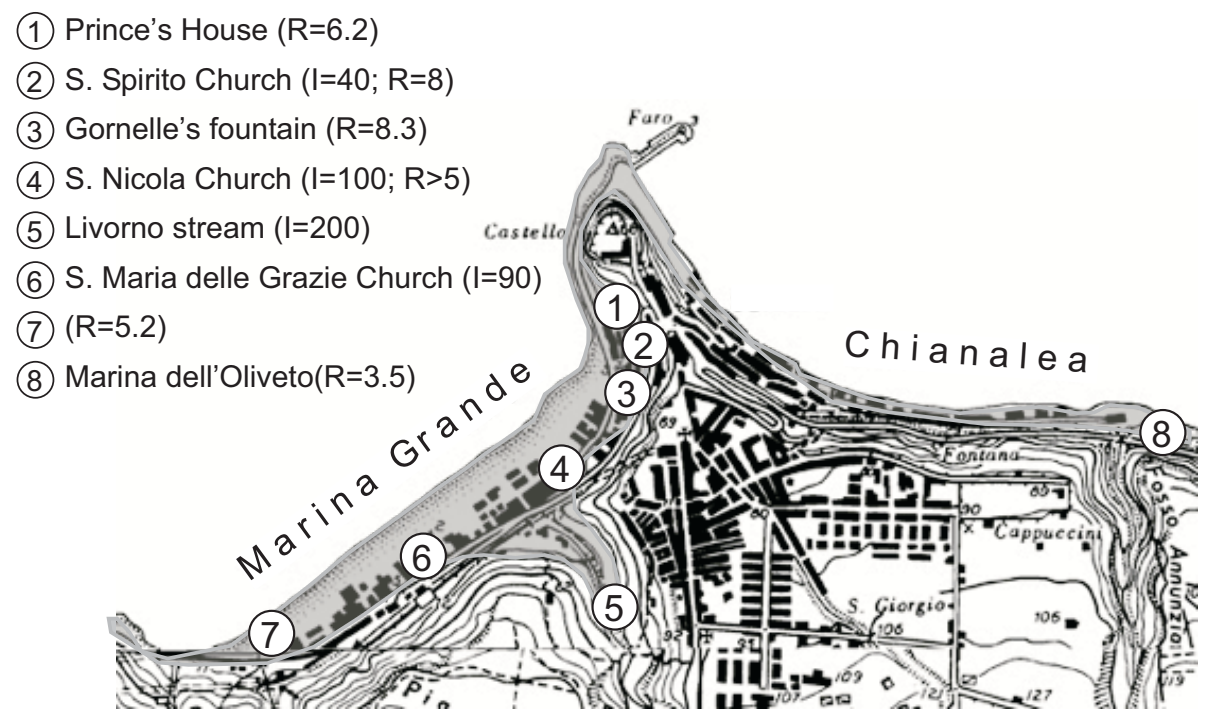

Fig. 5. Map of Scilla village: the area flooded by the 6 February 1783 tsunami is depicted in grey. Numbers indicate spots for which inundation and/or run-up values have been inferred by the bibliographical sources. Letter "I" indicates the inundation value (in meters), while " $\mathrm{R}$ " indicates the run-up value (in meters).

Tirreno the sea inundated the shore without any damage (Minasi, 1785). At Scilla the sea withdrew for more than $10 \mathrm{me}-$ ters leaving the sea bottom dry and a lot of fish on the beach; then suddenly the water came back surpassing its usual limit and flooding the coast (Sarconi, 1784). This detail is also reported by Minasi $(1785,1971)$ who tells that at Chianalea beach (Scilla), the sea withdrew by about $10 \mathrm{~m}$, leaving many fish aground, and coming back it surpassed the usual shoreline by about $1.5 \mathrm{~m}$. Minasi (1970) is the only one who further mentioned a secondary tsunami occurrence, reporting that at San Gregorio, close to Scilla, a piece of rock fell into the sea generating sea waves.

At Messina the sea water got over the quays in the harbour, inundating and destroying them; the Teatro Marittimo and nearby buildings along the shore were violently inundated (De Leone, 1783; Sarconi, 1784; Hamilton, 1783). The sea remained agitated as long as three days after the main shock.

At Torre del Faro (close to Messina), a first sea retreat was followed by an inundation (Sarconi, 1784). During the withdrawal many boats and some fishermen were dragged and fish were found on the shore (Anonymous Peloritano, 1783; De Leone, 1783). The water of the two marshes, called Pantano Piccolo and Pantano Grande, also receded (Vivenzio, 1788). On coming back, the sea partly destroyed the lighthouse and penetrated as far as the two marshes, inundating vineyards.

At Catona the sea flooded the coast for a short stretch (Sarconi, 1784). At Reggio Calabria the sea surpassed the beach arriving at the coastal road (Sarconi, 1784), inundating some town districts (De Leone, 1783). In the stretch of coast from Bianco to Roccella Ionica (about $35 \mathrm{~km}$ long) on the Ionian side of Calabria, the beach was flooded by about one mile
(Galimi, 1783). At Roccella, three big waves were observed about 7 min after the shock. The sea reached the monastery of the Padri Paolotti, carrying many boats inland (Minasi, 1785; De Lorenzo, 1877).

It is seen that the tsunami affected a very vast area including the southern part of the Tyrrhenian and Ionian coasts of Calabria as well as the Messina Straits coast, causing damage to structures and to boats in some places. As a result of this study the tsunami intensity has been re-evaluated, passing from 3 to 4 (Sieberg-Ambraseys scale), with reliability 4. We attribute PI intensity VI.

\subsection{February 1783 - time 00:20}

Very likely the earthquake is not directly responsible for the tsunami generation and the tsunami was due to a huge rockfall that was induced by the earthquake: in fact, a big portion of the Mount Campallà (that is located on the south-western side of the Scilla beach) collapsed into the sea about half an hour after the shock. The front of the failing mass was about $450 \mathrm{~m}$ long and penetrated the sea at most by $100 \mathrm{~m}$ according to Minasi (1785). From another source (De Lorenzo, 1895) we learn that the front was about $2 \mathrm{~km}$ long, with detachment occurring at a distance ranging from 500 to $2 \mathrm{~km}$ onshore, and that the mass penetrated the sea by a distance of $110 \mathrm{~m}$.

At Scilla most people, frightened by the sequence of earthquakes of 5 February, escaped to the open beach but during the night they were surprised by the unexpected waves (Hamilton, 1783; Sarconi, 1784; Minasi, 1785; Vivenzio, 1788; De Leone, 1783, Torcia, 1783; De Lorenzo, 1877). A few seconds after the rockfall, the sea violently inundated 


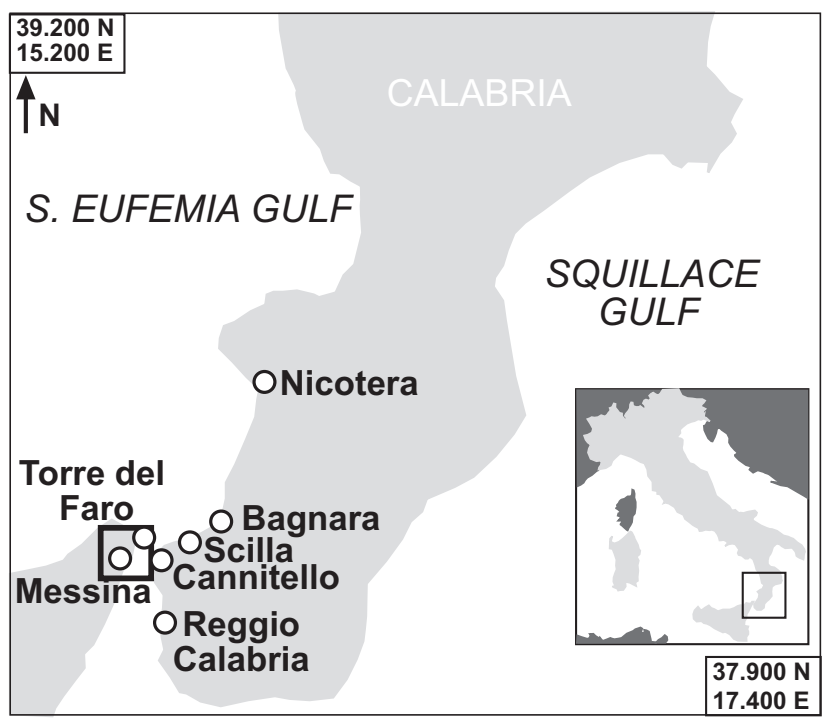

Fig. 6. Epicentre of the 6 February 1783 earthquake. Localities hit by the generated tsunami are reported.

the district of Marina Grande, and the water reached the roof of the buildings (Fig. 5). Three big flooding waves were observed. The water climbed the Livorno stream up to $200 \mathrm{~m}$ from the sea shore, then reached the beaches called Chianalea and Marina dell'Oliveto, that are located on the other side (north-east) of the Scilla promontory. At marina Grande, the Santo Spirito Church was destroyed, and the church of Santa Maria delle Grazie (at a distance of about $90 \mathrm{~m}$ from the shoreline) was inundated as well as the San Nicola Church. A woman was entangled in a mulberry tree at a height of $8.3 \mathrm{~m}$ near the Gornelle fountain (Anonymous Peloritano, 1783; De Lorenzo, 1877). The total number of victims due to the tsunami exceeded 1500 (Galimi, 1783; Mercalli, 1906). In Fig. 5 the map of the places affected by the waves is portrayed, with penetration distances and run-up values reported. According to Sarconi (1784), in the beach of Marina Grande the observed run-up heights range between 6-9 m, while according to Minasi (1785) the wave reached the maximum height of $16 \mathrm{~m}$.

The tsunami was seen even far from its source (Fig. 6). At Nicotera the sea withdrew and then inundated the shore carrying some fishing boats (De Leone, 1783) and also the coastal villages of Bagnara and Cannitello were affected by the inundation (Minasi, 1785; De Lorenzo, 1877). At Messina the sea was seen to rise and noisily overflowing the coast; waves were also quite relevant at the headlight. Minasi (1785) reports a sea level rising of about $2 \mathrm{~m}$. At Torre del Faro the coast was flooded for about 600 paces. Some boats and 26 victims were carried seaward (Sarconi, 1784; Torcia, 1783; Vivenzio, 1788) and the run-up height was about $6 \mathrm{~m}$. At Peloro, near Torre del Faro, a long stretch of fields was flooded, close to the small lake called Pantano Piccolo.

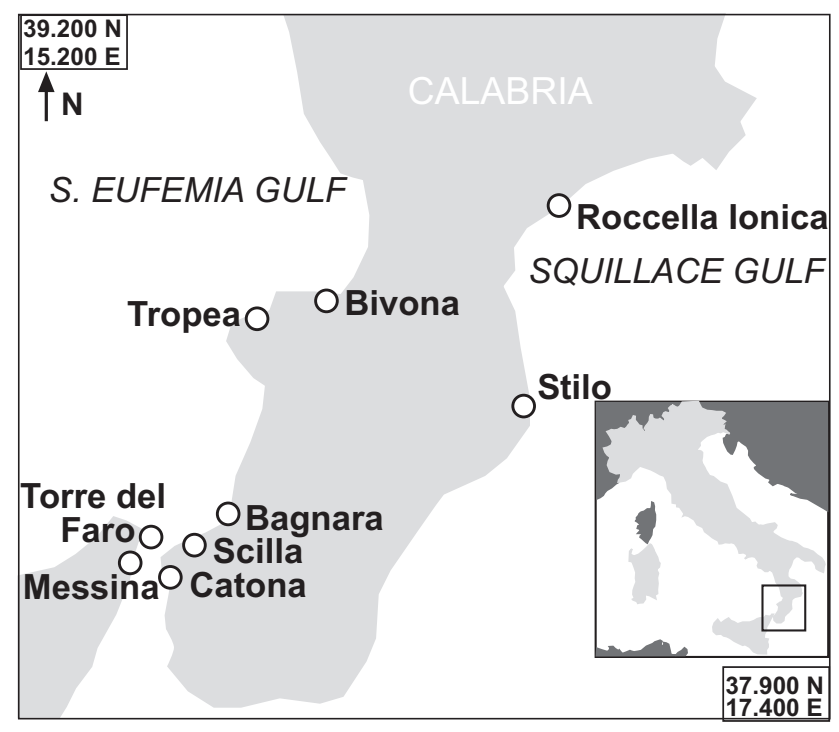

Fig. 7. Localities affected by the tsunamis of 7 February 1783; of 1 March 1783; of 28 March 1783; of 7 January 1784; of 9 January 1784; and of 19 January 1784.

Small houses, people and animals were carried seaward (Augusti, 1783; Torcia, 1783; Gallo, 1784). At Punta del Pezzo, close to Cannitello, and in the surrounding areas, sea covered the beach by one and a half mile, leaving sand on the ground (Sarconi, 1784). At Reggio Calabria the sea inundated the shore carrying a lot of heavy material (Torcia, 1783; De Leone, 1783).

The analysis of the sources put in evidence some new data about the tsunami, and confirmed its catastrophic impact. The event gets the highest reliability and intensity values, exactly as in the ITC, i.e. respectively 4 and 6 (SiebergAmbraseys scale). We attribute PI intensity X mostly on the basis of the high toll of human lives in Scilla.

\subsection{February 1783 - time 13:10}

In the CPTI2 (2004) catalogue an earthquake of equivalent magnitude $\mathrm{Me}=6.6$ ( $\mathrm{I}=\mathrm{X}-\mathrm{XI} \mathrm{MCS})$ is reported as occurred inland, about $200 \mathrm{~km}$ far from the coast. In the literature, only one piece of information has been found concerning a tsunami event at Stilo (Fig. 7), along the Ionian Calabrian coast, when the sea rose with no flooding (Vivenzio, 1788). The historical source mentioning the phenomenon is contemporary and it was proven to be very reliable in all cases where cross-checking was possible, and this is reason why the tsunami reliability value has been slightly changed, passing from 1 to 2 . The Sieberg-Ambraseys intensity is 2 , whereas the PI intensity is III. 


\subsection{March 1783 - time 01:40}

On 1 March 1783 the CPTI2 (2004) catalogue reports a shock (equivalent magnitude $\mathrm{Me}=5.9, \mathrm{I}=\mathrm{IX}-\mathrm{X} \mathrm{MCS}$ ) that occurred in land about $100 \mathrm{~km}$ far from the Tyrrhenian coast, to the north of the previous earthquakes areas. A contemporary source refers that along the shore at Tropea (Fig. 7) after the shock a considerable sea flooding was observed (Galimi, 1783). The available descriptions allow us to attribute to this tsunami intensity 2 (Sieberg-Ambraseys scale) and reliability 3. The PI intensity is III.

\subsection{March 1783 - time 12:00}

This is the second new event identified during our study. The available seismic catalogues do not report any earthquake occurred in that day. During this study we found two sources mentioning a tsunami that occurred on 24 March due to a rockfall of a big portion of the Mount Campallà, a little eastward to the site that was affected by the 6 February collapse. There is uncertainty about the year of occurrence: according to one source (Minasi, G., 1971) the rockfall occurred in 1783 while the other one (Minasi, A., 1970) reports 1790 as the year of occurrence. Both authors recount that at about 12:00 a.m. a big portion of Mount Campallà fell into the sea and that a small boat, that was in the vicinity, was capsized and one man died. It was certainly a local event, that apparently did not cause any damage along the shore. Reliability 4 can be attributed to this case. Attributing intensity is quite hard, since neither of the two scales (Sieberg-Ambraseys and Papadopoulos-Imamura) seem to fit the case of waves causing damage to boats offshore, but no damage at the coast. If attention is put on the aspect of boat damaging, the SiebergAmbraseys intensity can be estimated 3, while the PI intensity can be evaluated IV.

\subsection{March 1783 - time 18:55}

A very strong shock $(\mathrm{Me}=6.9, \mathrm{I}=\mathrm{X}-\mathrm{XI} ; \mathrm{CPTI} 2,2004)$ caused severe damage in the villages located between the S.Eufemia and the Squillace gulfs, both in the Tyrrhenian and the Ionian coasts (Fig. 7).

At Bagnara, a sea inundation occurred just after the shock (Galimi, 1783). No additional information was found about this event and, therefore, reliability and intensity values remained the same, respectively 3 and 2 (Sieberg-Ambraseys scale). The attributed PI intensity value is III.

\subsection{January 1784}

A light aftershock $(\mathrm{Me}=4.1, \mathrm{I}=\mathrm{VI}$; ING, 1991) took place with epicentre near Roccella Ionica. Here the sea flooded most of fields, causing damage and destroying some small houses (Vivenzio, 1788). No additional information has been found about this event that was very local since it affected only a single place, though with destructive power. Reliability is 4 . Assuming that the ruined houses were light structures, the Sieberg- Ambraseys intensity is 3, whereas the intensity according to the Papadopoulos and Imamura scale is VI.

\subsection{January 1784 - time 02:00}

This is the new identified tsunami event. The available seismic catalogues do not report any earthquake in that day. According to Vivenzio (1788), at Bivona (Fig. 7) during the night a strong submarine earthquake occurred and a ship in the harbour broke its mooring and ran aground. The available descriptions allow us to attribute intensity 3 (SiebergAmbraseys scale), PI intensity IV and reliability 2.

\subsection{January 1784}

A light aftershock (Me=4.1, I=IV; ING, 1991) occurred near Messina. An unusual sea agitation was observed between Torre del Faro and Scilla (Fig. 7). At Faro many banks were broken. At Fossa and Catona many fields were flooded with damage and a lot of trees were overturned (Vivenzio, 1788). Reliability is 4 . Putting emphasis on the bank damage at Faro, the Sieberg-Ambraseys tsunami intensity is 4 . The intensity according to the Papadopoulos and Imamura scale is VI.

\section{Conclusions}

An accurate revision of the 1783-1785 seismic crisis has been carried out, with the main purpose of understanding better the tsunami events associated with this crisis. All the events have been evaluated according to the criteria adopted for the compilation of the ITC with the aim of updating the catalogue. In addition the Papadopoulos-Imamura tsunami intensity was evaluated.

During this study the thorough analysis of the bibliographical sources permitted us to add more data to the tsunamis already included in the catalogue. For some events the new information implied a consequent change of the ITC reliability and/or intensity values.

Three new tsunami events have been discovered, two with intensity 3 and one with intensity 2 on the SiebergAmbraseys scale.

Edited by: E. Pelinovsky

Reviewed by: Y. Altinok and G. Papadopoulos 


\section{References}

Ambraseys, N. N.: Data for investigation of seismic sea waves in the Eastern Mediterranean, Bull. Seism. Soc. Am., 52, 895-913, 1962.

Anonymous Peloritano (Ignazio Paterno' castello Principe di Biscari): Descrizione del Terribile terremoto de' 5 febbraio 1783 che afflisse la Sicilia, distrusse Messina e gran parte della Calabria, Napoli, 1783.

Augusti, M.: Dei terremoti di Messina e di Calabria dell'anno 1783, memorie e riflessioni, Bologna, 1783.

Baratta, M.: I Terremoti d'Italia, Arnoldo Forni, Torino, 1901.

Boschi, E., Guidoboni, E., Ferrari, G., Mariotti, D., Valensise, G., and Gasperini, P.: Catalogue of strong Italian earthquakes from 461 b.C. to 1997, Ann. Geofis., 43 609-868, (also available on CD Rom), 2000.

CPTI2 - Gruppo di lavoro CPTI, 2004: Catalogo Parametrico dei Terremoti Italiani, Versione 2004, INGV, Bologna, 2004.

D'Agostino, N. and Selvaggi, G.: Crustal motion along the EurasiaNubia plate boundary in the Calabrian Arc and Sicily and active extension in the Messina Straits from GPS measurements, J.Geophys. Res., 109, B11402, doi:10.1029/2004JB002998, 2004.

De Leone, A.: Giornale e notizie de' tremuoti accaduti l'anno 1783 nella provincia di Catanzaro, Napoli, 1783.

De Lorenzo, A.: Memorie da servire alla storia sacra e civile di Reggio e delle Calabrie, Cronache e Documenti inediti o rari, vol. I, Reggio Calabria, 1877.

De Lorenzo, A.: Un secondo manipolo di monografie e memorie reggine e calabresi, Siena, 1895.

Dolomieu, D.: Mémoire sur le Tremblement de Terre de la Calabre Pendant l'Année 1783, Fulgoni, Rome, 1784.

Galimi, P.: Lettera di Procopio Galimi al signor D.Giuseppe Vairo sui tremuoti di Calabria dell'anno 1783.

Gallo, A.: Lettera istorico-fisica de' terremoti accaduti in Messina nel mese di febbraio di quest'anno 1783, Messina, 8 marzo 1783, Bologna, 1784.

Hamilton, W.: Relazione dell'ultimo terremoto delle Calabrie e delle Sicilia, inviata da Hamilton, S. E. G. e tradotta dal dottor Sella, G., Firenze, 1783.

ING (Istituto Nazionale di Geofisica): Catalogo dei terremoti italiani dal 1450 a.C. al 1990, Internal file, Roma, 1991.

Jacques, E., Monaco, C., Tapponier, P., Tortrici, L., and Winter, T.: Faulting and Earthquake triggering during the 1783 Calabria seismic sequence, Geophys. J. Int., 147, 499-516, 2001.
Jenny, S., Goes, S., Giardini, D., and Kahle, H. G.: Seismic potential of Southern Italy, Tectonophysics, 415, 81-101, 2006.

Mecalli, G.: Alcuni risultati ottenuti dallo studio del terremoto calabrese dell' 8 settembre 1905, Atti dell' Accademia Pontoniana di Napoli, 36, p. 1-9, 1906.

Minasi, G.: Continuazione ed appendice sopra i tremuoti descritti nella relazione colla data di Scilla de 30 settembre 1783, con altro che accadde in progresso, Messina, 1785.

Minasi, A.: La specola del filosofo, Natura e sorti nelle incisioni di Antonio Minasi, Ilario Principe, "Brutium", 1970.

Minasi, G.: Notizie storiche della città di Scilla, Edizioni Parallelo 38, Reggio Calabria, 1971.

Papadopoulos, G. A. and Imamura, F.: Proposal for a new tsunami intensity scale. Proc. Internat.Tsunami Conference, Seattle 7-9 August 2001, p. 569-577, 2001.

Monaco, C., Tortorici, L., Nicolich, R., Cernobori, L., and Costa, M.: From collisional to rifted basins: an example from southern Calabria arc (Italy), Tectonophysics, 266, 233-249, 1996.

Piatanesi, A., Tinti, S., and Gavagni, I.: The slip distribution of the 1992 Nicaragua earthquake from tsunami run-up data, Geophys. Res. Lett., 23, 37-40, 1996.

Sarconi, M.: Istoria de' fenomeni del tremuoto avvenuto nelle Calabrie e nel Valdemone nell'anno 1783, Napoli, 1784.

Tinti, S. and Maramai, A.: Catalogue of tsunamis generated in Italy and in Côte d'Azur, France: a step towards a unified catalogue of tsunamis in Europe, Annali di Geofisica, 39, 1253-1299, 1996.

Tinti, S., Maramai, A., and Graziani, L.: The New Catalogue of Italian Tsunamis, Nat. Hazards, 33, 439-465, 2004.

Tinti, S. and Piatanesi, A.: Numerical simulations of the tsunami induced by the 1627 earthquake affecting Gargano, Southern Italy, J. Geodynamics, 21, 141-160, 1996a.

Tinti, S. and Piatanesi, A.: Finite-element simulations of the 5 February 1783 Calabrian Tsunami, Phys. Chem. Earth, 21(12), 39-43, 1996b.

Torcia, M.: Tremuoto avvenuto nella Calabria e a Messina all 5 febbrajo 1783 descritto da Michele Torcia - Archiviario di S. M. Siciliana e Membro della Accademia Regia, Napoli, 1783.

Tortorici, G., Bianca, M., De Guidi, G., Monaco, C., and Tortorici, L.: Fault activity and marine terracing in the Capo Vaticano area (southern Calabria) during the Middle-Late Quaternary, Quat. Int., 101-102, 269-278, 2003.

Vivenzio, G.: Istoria de' tremuoti avvenuti nella provincia di Calabria ulteriore e nella città di Messina nell'anno 1783, Napoli, 1788 . 